Vol. 4: 35-48.

\title{
Effect of road traffic on heavy metal concentrations of plants
}

\author{
Toivo Yläranta \\ Agricultural Research Centre of Finland, Institute of Soils and Environment, \\ FIN-31600 Jokioinen, Finland
}

\begin{abstract}
The concentrations of zinc, copper, lead, cadmium and nickel in spring wheat grain and straw, Italian rye grass and lettuce were studied in a two-year field experiment conducted alongside two roads with a daily traffic density of 9500 and 5500 vehicles each. The experimental plots were located 22, 58 and $200 \mathrm{~m}$ from the roads. As controls, polyethylene pots filled with non-contaminated soil were placed in each plot.

The values for the bulk deposition of lead were $50 \%$ and those for dry deposition over $50 \%$ higher in the plot $22 \mathrm{~m}$ from the roadside than in the plot $200 \mathrm{~m}$ from the roadside. The bulk deposition of zinc also decreased slightly with distance from the road. Cadmium depositions were low at all experimental sites. The highest values for dry deposition of lead and cadmium were recorded when the wind blew from the road in the direction of the collectors.

The heavy metal concentrations varied from plant to plant but for a particular species were similar at different experimental sites. The highest zinc, cadmium and nickel concentrations were measured in lettuce. The lead concentration of wheat straw, Italian rye grass and lettuce at $22 \mathrm{~m}$ from the roadside was 1.5-3 times that of the background level at $200 \mathrm{~m}$. In wheat grain, the lead concentration was very low and did not change with distance from the road. The plants took up lead mainly from air deposition. The zinc concentration of wheat grain and the nickel concentration of Italian rye grass were also high. Cadmium concentrations were low in wheat grain and straw and in rye grass. In wheat, the zinc and copper concentrations were higher and the lead and cadmium concentrations much lower in grain than in straw.
\end{abstract}

Key words: pollution, bulk deposition, dry deposition

\section{Introduction}

The worldwide use of lead alkyls in petrol since 1923 has led to average lead emissions in the northern hemisphere of about $20 \mathrm{mg} \mathrm{m}^{-2}$ (Wick- ern and Breckle 1983). In 1988, estimated lead emissions in Finland totalled $47400 \mathrm{~kg}$, of which $76 \%$ was due to road traffic (Aunela and Larjava 1990). Some other heavy metals, e.g. zinc, copper, cadmium and nickel, are also spread by road traffic (Lagerwerff and Specht 1970, John- 
Yläranta, T.: Effect of road traffic on heavy metal concentrations of plants

ston and Harrison 1984, Albasel and Cottenie 1985, Ho and Tai 1988). Lead is not generally considered an essential microelement for either animals or humans. Its importance as an object of study is based on its toxicity when present in above-normal concentrations. Cadmium, however, may be benefical to animals in very small amounts (e.g. Anke et al. 1986). Zinc and copper are essential elements for plants and animals; so is nickel, as shown by some studies (Eskew et al. 1984). Plants do not have ion-selective systems to prevent them from taking up elements if these are available. Thus they always contain both essential and harmful elements and so are useful indicators of pollution.

The heavy metal concentrations of crops vary widely from one crop to another. Considerable differences also exist between the heavy metal concentrations of various parts of plants (Yläranta and Sillanpää 1984, Sillanpää et al. 1988, Sillanpää and Jansson 1991). Yläranta and Sillanpää (1984) measured the lowest copper concentration in the underground parts of some root crops and in the straws of grain crops. A fairly high zinc concentration was typical of grains. The lowest average lead concentration was determined on those plant parts which had been exposed to either no or limited external contamination by air. Considerably higher lead concentrations were found in crops or their parts in which exposure to air had been greater due either to their larger surface area or to a longer growth period (Sillanpää et al. 1988). Percentages as high as 90 or more of lead in plants are thought to derive from airborne lead (Tjell et al. 1979) In general, cereal grains were low in cadmium. The most effective cadmium collectors were root crops (Sillanpää and Jansson 1991).

The mean concentration of soluble lead in Finnish agricultural soils is higher than that of soluble nickel (Sippola and Tares 1978, Paasikallio 1978). In plants, however, the nickel concentration is higher than that of lead (Paasikallio 1978, Syvälahti and Korkman 1978). The tendency for elemental concentrations to be higher in leaves than in non-foliar edible parts applies to zinc, copper, lead and cadmium but not to nickel, which commonly has higher concentrations in edible parts than in leaves (Davis and Carlton-Smith 1980).

The aim of this study was to measure the concentration in plants of lead and some other elements that was due to airborne deposition, road traffic in particular. If the soil is contaminated, it is not sufficient to measure the elemental concentrations in soil and plants alone. Therefore, a special experimental technique was used in which pots filled with "clean" soil were placed on the plots located at different distances from the road. The elemental concentrations of plants growing on the plots and in the pots were then compared in order to establish what proportion was due to air deposition.

\section{Methods}

\section{Experimental fields}

The experiment was carried out in 1987 at two experimental sites in southern Finland: one by highway 3 at Nurmijärvi (NU, 60 $31^{\prime} \mathrm{N}, 23^{\circ}$ $\left.51^{\prime} \mathrm{E}\right)$ and one by highway 2 at Jokioinen (JO, $\left.60^{\circ} 53^{\prime} \mathrm{N}, 23^{\circ} 28^{\prime} \mathrm{E}\right)$. In 1988 , the experiment was carried out at Jokioinen only, and a field (JOK, $60^{\circ} 41^{\prime} \mathrm{N}, 23^{\circ} 21^{\prime} \mathrm{E}$ ) located far from any busy roads was chosen as a reference site. To avoid contamination disturbances, the experimental sites were in locations without any emission sources or natural obstacles in the vicinity. The road surface at Nurmijärvi was $2.5 \mathrm{~m}$ and at Jokioinen $2 \mathrm{~m}$ above the level of the adjacent experimental field. The roads were $6 \mathrm{~m}$ wide and asphalted. The road at Nurmijärvi runs from south to north and that at Jokioinen from southeast to northwest. Thus, at Nurmijärvi the fields were west of the road $\left(90^{\circ}\right)$ and at Jokioinen northeast $\left(30^{\circ}\right)$. The daily traffic density at Nurmijärvi was 9500 and at Jokioinen 5500 cars. The main wind directions were southerly, southeasterly, westerly and northeasterly for the experimental plots at Nurmijärvi as measured at 
Vol. 4: 35-48.

\section{Experimental field:}

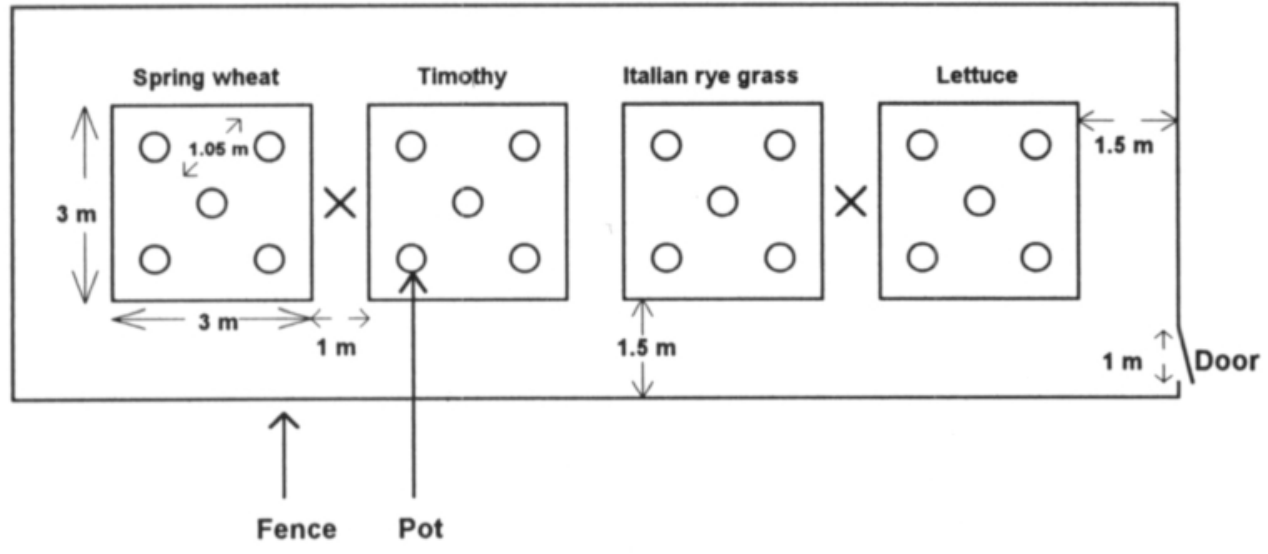

\section{Bulk sample collector}

Fig. 1. Schematic diagram of the experimental field.

Tuusula, about $15 \mathrm{~km}$ to the southeast of Nurmijärvi, and southerly to westerly for Jokioinen, as measured in 1987 and 1988 at the meteorological station $10 \mathrm{~km}$ to the southeast of the experimental site. The experimental plots were located on arable land that had long been used for normal cultivation practices, mostly for growing cereals.

Plots, $3 \times 3 \mathrm{~m}^{2}$ in size growing spring wheat (Triticum aestivum, cv. Ruso), Australian lettuce (Lactuca sativa) or Italian rye grass (Lolium multiflorum L., cv. Amenda), were established at each experimental site (Fig. 1). The plots lay $22 \mathrm{~m} \mathrm{(JO} \mathrm{I,} \mathrm{NU} \mathrm{I),} 58 \mathrm{~m}$ (JO II, NU II) and $200 \mathrm{~m}$ (JO III, NU III) from the roadside, respectively.

The plough layer $(0-25 \mathrm{~cm})$ of experimental soils (NU and JO) was heavy clay except at JOK, where it was sandy (Table 1). On JO and NU fields, the particle size distribution was finer in the deeper layer $(30-60 \mathrm{~cm})$ than in the plough layer. At JOK the deeper layer was clay soil.

Pure HD polyethylene pots, 30 litres in capacity, $42 \mathrm{~cm}$ in height and $30 \mathrm{~cm}$ in diameter, were placed on each plot. The pots were filled with sandy soil in 1987 (16.5 kg of dry matter) and with Carex peat in 1988 (7.0 kg of dry matter). The bottom of each pot was covered with 8 $\mathrm{kg}$ of coarse quartz gravel $(\varnothing 8-16 \mathrm{~mm})$ to a height of $12 \mathrm{~cm}$ and topped with $3 \mathrm{~kg}$ of fine quartz gravel ( $\emptyset 3-5 \mathrm{~mm}$ ) to prevent the pot soil from mixing with the coarse gravel. The quartz gravels were washed with $4 \mathrm{M} \mathrm{HCl}$, and rinsed with tap water and finally deionized water until all acidity had been washed out. The gravels prevented the plant roots from growing from the pots into the soil.

The fertilizers used annually were pure chemicals (Merck, p.a.) dissolved in deionized water:

$$
\begin{aligned}
& \text { N } 100 \mathrm{~kg} \mathrm{ha}^{-1}\left(\mathrm{NH}_{4} \mathrm{NO}_{3}, \mathrm{KNO}_{3}\right) \\
& \text { P } 31 \mathrm{~kg} \mathrm{ha}^{-1}\left(\mathrm{KH}_{2} \mathrm{PO}_{4}\right) \\
& \text { K } 80 \mathrm{~kg} \mathrm{ha}^{-1}\left(\mathrm{KNO}_{3}, \mathrm{KH}_{2} \mathrm{PO}_{4}\right)
\end{aligned}
$$

In 1988, magnesium (71 kg/ha) and sulphur $(94 \mathrm{~kg} / \mathrm{ha})$ fertilization was also given as $\mathrm{MgSO}_{4}$ $x 7 \mathrm{H}_{2} \mathrm{O}$. In both years, the fertilization in the pots was twice that in the plots.

In the plots, the fertilization solution was placed at a depth of $7 \mathrm{~cm}$ in 12 rows $25 \mathrm{~cm}$ apart. The seed rows crossed the rows with fertilizer. 
Yläranta, T.: Effect of road traffic on heavy metal concentrations of plants

Table 1. Soil sample means of JO I-III, NU I-III, JOK and pots for $\mathrm{pH}\left(\mathrm{CaCl}_{2}\right)$, organic carbon content $(\mathrm{OC}, \%)$ and particle size distribution (clay $<0.002$, silt $0.002-0.02$, fine sand $0.02-0.2$ and coarse sand $0.2-2 \mathrm{~mm}$ ).

\begin{tabular}{|c|c|c|c|c|c|c|c|}
\hline & Layer, & & & & & & \\
\hline & $\mathrm{cm}$ & $\mathrm{pH}$ & $\mathrm{OC}$ & Clay & Silt & Fine & Coarse \\
\hline JO I & $0-25$ & 5.6 & 4.0 & 68 & 17 & 9 & 6 \\
\hline & $30-60$ & 6.0 & 0.5 & 80 & 9 & 10 & 1 \\
\hline JO II & $0-25$ & 5.1 & 3.4 & 69 & 16 & 9 & 6 \\
\hline & $30-60$ & 5.8 & 0.6 & 84 & 6 & 8 & 2 \\
\hline JO III & $0-25$ & 5.2 & 3.1 & 69 & 12 & 10 & 9 \\
\hline & $30-60$ & 5.6 & 0.6 & 86 & 4 & 8 & 1 \\
\hline NU I & $0-25$ & 5.5 & 3.9 & 69 & 18 & 8 & 5 \\
\hline & $30-60$ & 6.2 & 0.7 & 79 & 11 & 8 & 2 \\
\hline NU II & $0-25$ & 5.5 & 4.1 & 71 & 19 & 7 & 3 \\
\hline & $30-60$ & 6.3 & 0.4 & 78 & 12 & 10 & 0 \\
\hline NU III & $0-25$ & 5.8 & 3.8 & 74 & 18 & 6 & 2 \\
\hline & $30-60$ & 6.3 & 0.4 & 78 & 10 & 10 & 2 \\
\hline JOK & $0-25$ & 6.3 & 2.8 & 26 & 16 & 35 & 23 \\
\hline & $30-60$ & 6.3 & 0.6 & 48 & 21 & 25 & 6 \\
\hline Pot soi & & & & & & & \\
\hline Sand & & 5.8 & 6.1 & 5 & 6 & 62 & 27 \\
\hline Care & & 6.0 & 37 & - & - & - & - \\
\hline
\end{tabular}

Wheat $(300 \mathrm{~g})$ and Italian rye grass $(10 \mathrm{~g})$ were sown in 25 and lettuce $(10 \mathrm{~g})$ in 12 rows: wheat at a depth of $5 \mathrm{~cm}$ and Italian rye grass and lettuce at a depth of $2-3 \mathrm{~cm}$. In the pots, the fertilization and seed depths were about the same as in the adjacent plot. The amount of seeds sown in the pots was one-tenth of that sown in the plots.

The plants were cut with stainless steel scissors, avoiding contamination by soil as far as possible. Thus, after being cut, the plant parts from nearest the soil were rinsed with deionized, ultra-pure water (Millipore Milli-Q Water purification system). Lettuce was cut when the main growth had finished but the leaves were still fully green. Rye grass was cut at the silage stage (two yields in 1987 and three in 1988). Fertilization after the first cut was the same as that for the first cut but, in the pots, it was given in two lots 10 days apart. Spring wheat - both grain and straw - was harvested at the mature stage. The whole growth was harvested from each pot. A plant sample two to three times the size of the pot yield was harvested from the plot around each pot. Each plot sample consisted of six subsamples. The samples were placed into paper bags and dried at $60^{\circ} \mathrm{C}$. Finally, the plant growth on all plots was harvested and the dry matter yields were determined.

\section{Bulk and dry deposition sampling}

Two NILU (Norsk Institut for Luftforskning, Lillestrøm, Norway) deposit gauges with 2-litre bottles, one for nitrogen, sulphur and phosphorus (NSP) and one for the heavy metals zinc, copper, lead, cadmium and nickel (ME), were placed on each experimental field. The deposit gauges were of a funnel type with a cylindrical nylon mesh on the bottom of the funnel to prevent insects from getting trapped in the bottle. The HD polyethylene collectors were placed in a stainless steel frame at a height of $1.8 \mathrm{~m}$ (SFS 3865). Concentrated $\mathrm{HNO}_{3}(4 \mathrm{ml}$, Merck Suprapur, Art. 441) diluted with $10 \mathrm{ml}$ of deion- 


\section{AGRICULTURAL SCIENCE IN FINLAND}

Vol. 4: 35-48.

ized, ultra-pure water was added to the bottle intended for heavy metal collection to prevent absorption of the elements on the walls of the bottle.

The bottles were emptied weekly or when the volume of water collected was sufficient for elemental analysis. The collector gauge was rinsed with $50 \mathrm{ml}$ of $0.1 \mathrm{M} \mathrm{HNO}_{3}$ (ME) or $50 \mathrm{ml}$ of ultra-pure water (NSP). The total volume of water in the collector bottle was then measured and the water transferred to an LD polyethylene bottle.

In 1988, dry deposition was collected at JO I and JO III on a 47-mm teflon filter (Millipore FALP04700, pore size $1 \mu \mathrm{m}$ ) using a Nucleopore Swin-Lok douple holder adapter and TTL-1 dust collectors (Levy Ky, Helsinki, Finland). Sartorius $\mathrm{PC}$ membrane ( $\mathrm{SN}$ : 111132 , pore size $8 \mu \mathrm{m}$ ) was used as a prefilter for the Millipore FA filter. The filters were changed twice a week. During this time $100-200 \mathrm{~m}^{3}$ of air was passed through the filters.

\section{Analytical methods}

The zinc, copper, lead, cadmium and nickel in the experimental soils were extracted with acid ammonium acetate-EDTA (HAAC-EDTA, Lakanen and Erviö 1971) and aqua regia (AR, $0.5 \mathrm{~g}$ soil boiled for $2 \mathrm{~h}$ in a mixture of $7.5 \mathrm{ml}$ conc. $\mathrm{HCl}$ and $2.5 \mathrm{ml}$ conc. $\mathrm{HNO}_{3}$, Kick et al. $1980)$ and analysed by ICP-AES ( $\mathrm{Zn}, \mathrm{Cu})$ and ET-AAS ( $\mathrm{Pb}, \mathrm{Cd}, \mathrm{Ni})$. The zinc, copper, calcium, magnesium, potassium and phosphorus concentrations in the plant samples were determined with ICP-AES after dry ashing (Sillanpää and Jansson 1992); the sulphur concentration was determined after wet digestion by slightly modifying the method of Huang and Schulte (1985). The concentrations of lead, cadmium and nickel in plant samples were determined with ET-AAS after dry ashing (Sillanpää and Jansson 1992).

Total nitrogen in deposition was determined by oxidizing inorganic and organic nitrogen compounds into nitrate in alkaline solution. The oxidation was done under pressure $(200 \mathrm{kPa}$, $120^{\circ} \mathrm{C}$ ) for $0.5 \mathrm{~h}$. The nitrate concentration was determined by reducing the nitrate into nitrite in a copper-cadmium column according to the Finnish recommendation for the standard nitrate nitrogen method (SFS 3031). The determination was done on NSP samples with an autoanalyser. Sulphur, phosphorus, zinc, copper and nickel were analysed on acidified ME samples $(0.1 \mathrm{M}$ $\mathrm{HNO}_{3}$, Merck Suprapur) with ICP-AES and lead and cadmium with ET-AAS.

To determine the dry deposition of lead and cadmium, the teflon filters were cut into four pieces of equal size. The two crossing parts of each filter chosen for lead and cadmium analyses were digested in a teflon beaker. A mixture of $3 \mathrm{ml}$ of concentrated $\mathrm{HNO}_{3}$ (Merck Suprapur, Art. 441) and $0.75 \mathrm{ml}$ of concentrated $\mathrm{H}_{2} \mathrm{O}_{2}$ (Merck p.a. Art. 7209) was added to the beaker. The solution was evaporated to $1 \mathrm{ml}$ on an electrical plate and $3 \mathrm{ml}$ of concentrated $\mathrm{HCl}$ (Merck Suprapur, Art. 318) was added. The solution was evaporated to just under $1 \mathrm{ml}$, and $10 \mathrm{ml}$ of Milli-Q water was added. The beaker was left for $20 \mathrm{~min}$. in a Branson Ultrasonic Cleaner with the heat button on. The solution was transferred quantitively into a $25-\mathrm{ml}$ measuring flask. Lead and cadmium were analysed on the digestion solution with ET-AAS.

\section{Results and discussion}

\section{Soil characteristics}

The concentrations of HAAC-EDTA-extractable zinc, copper, lead and nickel in the experimental soils were very low compared with the AR extractable concentrations (Table 2). In contrast, one-third or more of aqua regia-extractable cadmium was also extractable into HAAC-EDTA. The results of the AR analyses confirmed the low zinc, copper, lead and nickel concentrations in coarse JOK and pot soil and also in Carex peat pot soil.

The HAAC-EDTA-extractable copper, lead, cadmium and nickel concentrations in the plough 


\section{AGRICULTURAL SCIENCE IN FINLAND}

Yläranta, T.: Effect of road traffic on heavy metal concentrations of plants

Table 2. Soil sample means for HAAC-EDTA and aqua regia-extractable $\mathrm{Zn}, \mathrm{Cu}, \mathrm{Pb}, \mathrm{Cd}, \mathrm{Ni}$ (mg/kg of dry soil).

\begin{tabular}{|c|c|c|c|c|c|c|c|c|c|c|c|}
\hline & & & & AC-E & & & & & A RE & & \\
\hline & $\begin{array}{c}\text { Layer, } \\
\mathrm{cm}\end{array}$ & $\mathrm{Zn}$ & $\mathrm{Cu}$ & $\mathrm{Pb}$ & $\mathrm{Cd}$ & $\mathrm{Ni}$ & $\mathrm{Zn}$ & $\mathrm{Cu}$ & $\mathrm{Pb}$ & $\mathrm{Cd}$ & $\mathrm{Ni}$ \\
\hline JO I & $0-25$ & 1.3 & 7.4 & 5.5 & 0.10 & 2.1 & 148 & 50 & 34 & 0.19 & 55 \\
\hline & $30-60$ & 0.8 & 4.8 & 3.9 & 0.04 & 2.0 & & & & & \\
\hline JO II & $0-25$ & 1.4 & 7.1 & 4.5 & 0.12 & 1.8 & 159 & 49 & 34 & 0.21 & 44 \\
\hline & $30-60$ & 1.1 & 5.0 & 4.1 & 0.02 & 2.4 & & & & & \\
\hline JO III & $0-25$ & 1.5 & 6.3 & 4.3 & 0.09 & 1.8 & 160 & 47 & 30 & 0.41 & 46 \\
\hline & $30-60$ & 1.1 & 5.4 & 3.4 & 0.04 & 2.1 & & & & & \\
\hline NU I & $0-25$ & 1.8 & 9.3 & 6.2 & 0.13 & 3.0 & 176 & 57 & 31 & 0.26 & 49 \\
\hline & $30-60$ & 0.9 & 4.4 & 4.1 & 0.03 & 1.6 & & & & & \\
\hline NU II & $0-25$ & 2.8 & 9.0 & 6.4 & 0.13 & 2.8 & 165 & 59 & 28 & 0.34 & 55 \\
\hline & $30-60$ & 0.9 & 4.3 & 4.4 & 0.04 & 2.1 & & & & & \\
\hline NU III & $0-25$ & 1.3 & 8.8 & 6.3 & 0.11 & 2.7 & 188 & 58 & 24 & 0.30 & 69 \\
\hline & $30-60$ & 1.3 & 4.4 & 4.2 & 0.04 & 2.9 & & & & & \\
\hline JOK & $0-25$ & 2.5 & 4.5 & 2.6 & 0.09 & 1.0 & 82 & 20 & 14 & 0.22 & 23 \\
\hline & $30-60$ & 0.4 & 3.2 & 1.7 & 0.02 & 1.1 & & & & & \\
\hline Pot soi & & & & & & & & & & & \\
\hline Sanc & & 1.6 & 2.2 & 1.1 & 0.10 & 0.41 & 25 & 8.4 & 7.8 & 0.23 & 8.6 \\
\hline Care & & 9.5 & 13 & 1.4 & 0.23 & 5.7 & 49 & 42 & 18 & 0.47 & 20 \\
\hline
\end{tabular}

layer of the experimental plots were higher and the zinc concentration was lower (Table 2) than on average in Finnish cultivated soils (Erviö et al. 1990). The zinc concentration was also low in mineral pot soil and JOK soil, which were of coarser texture than other soils. The zinc concentrations were, however, within the large range of zinc in Finnish cultivated soils. The HAACEDTA-extractable nickel concentration was clearly lower in sandy pot soil than in plot soils. The concentrations of HAAC-EDTA-extractable heavy metals were somewhat lower in the deeper layer than in the plough layer, excluding the concentration of cadmium, which was very low in the deeper layer. The high concentrations of cadmium, copper, lead and nickel in the experimental soils were attributed to the high clay content, which exceeded that in the data published by Erviö et al. (1990). The use of fertilizer containing cadmium probably raised the soil cadmium content. The HAAC-EDTA-extractable lead concentration in the plough layer on the JO fields and the AR-extractable lead concentration on the NU fields decreased with distance from the road, indicating the impact of traffic. Compared with levels reported in many other studies, the roadside lead concentration was very low (e.g. Lagerwerff and Specht 1970, Davies et al. 1979, Collins 1984). The decrease in HAACEDTA-extractable copper concentrations in plough layers with distance can also be explained by traffic.

\section{Deposition}

The annual bulk deposition of lead estimated from the data in Table 3 was of the same magnitude and the deposition of zinc and cadmium lower than measured in southern and central Sweden in 1984-1985 (Andersson and Gustafson 1988). In this study the measured copper deposition was higher and the nickel deposition much higher than the levels reported by Andersson and 


\section{AGRICULTURAL SCIENCE IN FINLAND}

Vol. 4: 35-48.

Table 3. Precipitation (Prec.) and bulk deposition of some elements at the experimental sites from June 1, 1987 to October 12, 1987 (1987) and from May 31, 1988 to September 20, 1988 (1988).

\begin{tabular}{|c|c|c|c|c|c|c|c|c|c|}
\hline \multirow[t]{2}{*}{ Site } & \multirow{2}{*}{$\begin{array}{c}\text { Prec. } \\
\text { mm }\end{array}$} & $\mathrm{N}$ & $\mathrm{S}$ & $\mathrm{P}$ & $\mathrm{Zn}$ & $\mathrm{Cu}$ & $\mathrm{Pb}$ & $\mathrm{Cd}$ & $\mathrm{Ni}$ \\
\hline & & \multicolumn{3}{|c|}{$\mathrm{kg} \mathrm{ha}^{-1}$} & \multicolumn{5}{|c|}{$\mathrm{g} \mathrm{ha}^{-1}$} \\
\hline \multicolumn{10}{|l|}{1987} \\
\hline JO I & 373 & 3.4 & 3.5 & 0.23 & 25 & 16 & 24 & 0.20 & 22 \\
\hline JO II & 375 & 3.5 & 3.5 & 0.16 & 18 & 11 & 17 & 0.18 & 28 \\
\hline JO III & 376 & 3.3 & 3.4 & 0.08 & 21 & 40 & 16 & 0.20 & 27 \\
\hline NU I & 325 & 2.9 & 3.0 & 0.13 & 24 & 25 & 27 & 0.19 & 20 \\
\hline NU II & 322 & 3.0 & 2.8 & 0.11 & 16 & 15 & 17 & 0.16 & 31 \\
\hline NU III & 319 & 3.0 & 2.8 & 0.10 & 20 & 66 & 15 & 0.22 & 39 \\
\hline JOK & 335 & 3.0 & 3.1 & 0.14 & 29 & 7 & 12 & 0.18 & 17 \\
\hline \multicolumn{10}{|l|}{1988} \\
\hline JO I & 243 & 2.1 & 1.9 & 0.07 & 19 & 41 & 14 & 0.30 & 25 \\
\hline JO II & 246 & 2.0 & 1.9 & 0.07 & 13 & 38 & 10 & 0.09 & 23 \\
\hline JO III & 248 & 1.8 & 1.9 & 0.10 & 9 & 39 & 7 & 0.23 & 28 \\
\hline JOK & 243 & 1.8 & 2.0 & 0.07 & 20 & 33 & 7 & 0.16 & 21 \\
\hline
\end{tabular}

Gustafson (1988). Hovmand et al. (1983) reported that the monthly bulk deposition of cadmium during the growth period in Denmark was 0.12$0.26 \mathrm{~g} \mathrm{ha}^{-1}$, which was about the same as that found here during over four months. With the exception of copper, the bulk deposition of elements was of the same magnitude at both experimental sites. In 1987, copper deposition was highest at $200 \mathrm{~m}$ from the roads. The lowest bulk deposition of heavy metals was measured on a field at Jokioinen, which can be considered a typical "clean" area in southern Finland. Traffic density is higher at Nurmijärvi than at Jokioinen, and thus higher lead deposition could be expected at Nurmijärvi. The relatively high lead deposition found at Jokioinen may be due to the wind, which frequently blew from the road towards the experimental plots. The cadmium values in the air were as low on JO I, the field nearest the road, as on the "backround" field, JO III, $200 \mathrm{~m}$ from the road (Fig. 3). The highest lead and cadmium concentrations (Figs 2 and 3) in the air during June and July correlated closely with the direction of the wind.

Zinc deposition decreased with an increase in distance from the road. Similar findings have been reported by Albasel and Cottenie (1985) for lead and zinc and by Johnston and Harrison (1984) for cadmium, copper and lead. In the study of Johnston and Harrison (1984), the deposition rate fell slowly beyond $20 \mathrm{~m}$, and reached "background" levels by over $200 \mathrm{~m}$, which distance was taken as the background in this study, too. In both of the above studies, the traffic density was much higher than in this study. The highest lead concentration in the air found here (Fig. 2) was less than one-tenth of the lowest acceptable limit value set by WHO (1987) or, on average, one-tenth of that measured in a central London park (Jensen and Laxen 1987).

\section{Metal uptake by plants}

In most cases, the yields did not vary much within the plots or from plot to plot (Table 4-7). No abnormal differences in calcium, magnesium, potassium, phosphorus or sulphur concentrations were seen between plants grown on plots and those grown in pots. Therefore, these figures are omitted from the final results.

The data published by Davies et al. (1979) 
Yläranta, T.: Effect of road traffic on heavy metal concentrations of plants

$\mathrm{Pb}\left(\mathrm{ng} / \mathrm{m}^{3}\right)$

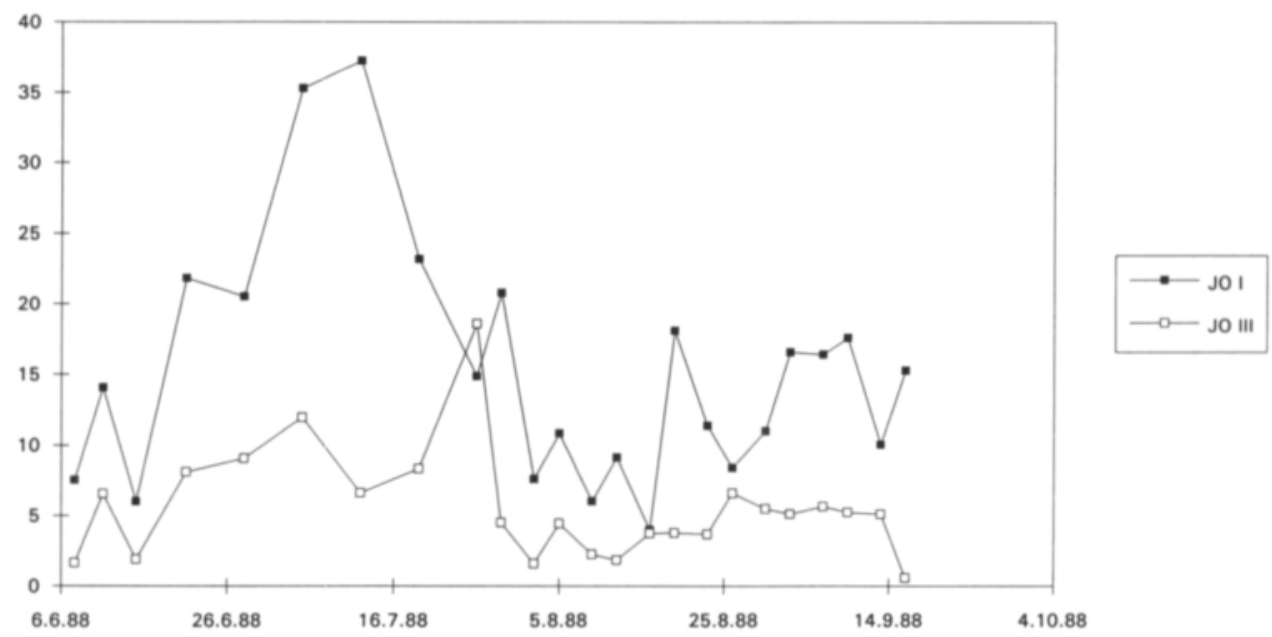

Fig. 2. Dry deposition of $\mathrm{Pb}$ measured from dust filters. Each point presents sampling for 3-4 days. The squares are joined by a line for ease of readability.

suggest that an accumulaltion of EDTA-extractable lead of approximately $350 \mathrm{mg} \mathrm{kg}^{-1}$ is necessary before radish will absorb sufficient lead to cause concern. This value is very much higher than that analysed on the HAAC-EDTA extracts in this study (Table 2).
The lead concentration of plants was commonly highest on the plots and in the pots closest to the roads (Table 4-7), where lead depositions were also highest (Table 3, Fig. 2). However, in wheat grain, the lead concentration was very low and did not change with distance from

Cd $\left(n g / m^{3}\right)$

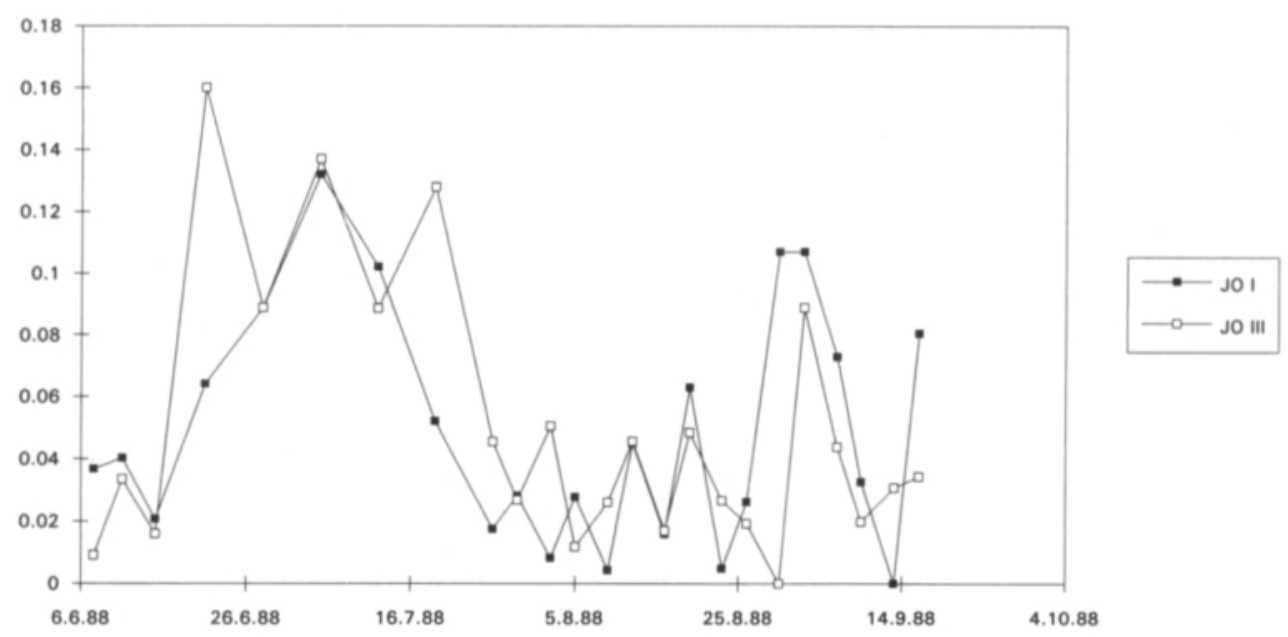

Fig. 3. Dry deposition of Cd measured from dust filters. Otherwise as in Fig. 2. 
Vol. $4: 35-48$.

Table 4. Mean dry matter yield (g/plot or pot) and heavy metal concentrations ( $\mathrm{mg} / \mathrm{kg}$ of dry matter) of lettuce at various distances from the roads at Nurmijärvi and Jokioinen in 1987.

\begin{tabular}{|c|c|c|c|c|c|c|}
\hline & \multicolumn{3}{|c|}{ Nurmijärvi } & \multicolumn{3}{|c|}{ Jokioinen } \\
\hline & $22 \mathrm{~m}$ & $58 \mathrm{~m}$ & $200 \mathrm{~m}$ & $22 \mathrm{~m}$ & $58 \mathrm{~m}$ & $200 \mathrm{~m}$ \\
\hline \multicolumn{7}{|l|}{ Lettuce } \\
\hline \multicolumn{7}{|l|}{ Plots } \\
\hline Yield & 780 & 770 & 1290 & 1450 & 1590 & 1260 \\
\hline $\mathrm{Zn}$ & $47^{2}(1$ & $42^{a}(1$ & $45^{a}(1$ & $35^{\mathrm{a}}(1$ & $37^{2}(1$ & $34^{a}(1$ \\
\hline $\mathrm{Cu}$ & $8.0^{\mathrm{a}}(2$ & $7.8^{\circ}(2$ & $9.0^{\circ}(2$ & $6.1^{2}(2$ & $7.7^{2}(2$ & $6.1^{2}(2$ \\
\hline $\mathrm{Pb}$ & $0.87^{a}$ & $0.45^{b}(3$ & $0.32^{\mathrm{b}}$ & $0.58^{\mathrm{a}}$ & $0.35^{\mathrm{b}}(3$ & $0.32^{\mathrm{b}}$ \\
\hline $\mathrm{Cd}$ & $0.97^{a}(3$ & $1.12^{a}(4$ & $0.56^{\mathrm{b}}$ & $0.77^{a}(3$ & $0.59^{\mathrm{ab}}$ & $0.51^{b}(3$ \\
\hline $\mathrm{Ni}$ & $1.79^{\prime \prime}(4$ & $1.54^{\mathrm{a}}(5$ & $1.18^{\mathrm{b}}(3$ & $2.06^{a}(4$ & $1.80^{\circ}(4$ & $1.43^{a}(4$ \\
\hline \multicolumn{7}{|l|}{ Pots } \\
\hline Yield & $21.6^{\mathrm{a}}$ & $16.5^{\mathrm{ab}}$ & $15.3^{b}$ & $19.0^{\mathrm{a}}$ & $20.2^{\mathrm{a}}$ & $21.7^{\mathrm{a}}$ \\
\hline $\mathrm{Zn}$ & $32^{a}(1$ & $32^{a}(1$ & $36^{a}(1$ & $26^{a}(1$ & $28^{\mathrm{a}}(1$ & $25^{\circ}(1$ \\
\hline $\mathrm{Cu}$ & $4.9^{\mathrm{a}}(2$ & $5.1^{2}(2$ & $5.7^{a}(2$ & $3.8^{b}(2$ & $5.0^{\circ}(2$ & $4.2^{a}(2$ \\
\hline $\mathrm{Pb}$ & $0.96^{\mathrm{a}}$ & $0.57^{b}(3$ & $0.39^{b}$ & $0.65^{\mathrm{a}}$ & $0.50^{b}(3$ & $0.36^{c}$ \\
\hline $\mathrm{Cd}$ & $0.54^{a}(3$ & $0.67^{a}(4$ & $0.71^{\mathrm{a}}$ & $0.38^{\mathrm{a}}(3$ & $0.49^{a}$ & $0.39(3$ \\
\hline $\mathrm{Ni}$ & $0.41^{a}(4$ & $0.31^{2}(5$ & $0.36^{a}(3$ & $0.88^{\mathrm{a}}(4$ & $0.49^{\prime}(4$ & $0.41(4$ \\
\hline
\end{tabular}

Means not marked with a common letter differ from each other at the $1 \%$ level of significance (Tukey's HSD, Honestly Significant Difference, test). Mean heavy metal concentration on the plots and in pots marked with the same number differ from each other at the $1 \%$ level of significance (t-test). The fields were tested separately.

the road. Ward et al. (1979) have reported anomalous lead levels in vegetation in the downwind direction at a similar traffic density. The influence of automotive emissions extends as a lead halo within $30-50 \mathrm{~m}$ of the road (Ward et al. 1979, Crump and Barlow 1982, RodríguesFlores and Rodrígues-Castellón 1982), which is about the same distance as measured here. Because plants take up lead mainly from air deposition (e.g. Ward et al. 1979), those grown on plots and in pots received about the same lead concentrations.

The highest zinc, cadmium and nickel concentrations were recorded in lettuce (Table 4$6)$. The zinc concentration of wheat grain and the nickel concentration of Italian rye grass were also high. The cadmium concentration was low in wheat and rye grass. In wheat, the zinc and copper concentrations were higher and the lead and cadmium concentrations much lower in grain than in straw. The high copper deposition at 200 $\mathrm{m}$ from the roads did not affect the copper con- centration of plants. The coarse pot soil was poor in zinc, copper and nickel, which probably explains the higher metal concentration often measured in plants grown on the plots than in those grown in pots.

Plants readily accumulate atmospheric cadmium (Hovmand et al. 1983, Naturvårdsverket 1987). Here the behaviour of cadmium differed from that of the other heavy metals. Its concentration was mostly higher on plots than in pots of lettuce but always higher in pots than on plots of wheat grain and, in most cases, also in the first cut of rye grass. Ho and Tai (1988) reported a good correlation between traffic flow and zinc, copper and cadmium concentrations in grass sampled within $3 \mathrm{~m}$ of the road kerb. Ward et al. (1977) showed that the relationship between heavy metal concentrations in plants and traffic volume also depends on the plant species concerned. These findings together with the low zinc, copper, cadmium and nickel concentrations measured in roadside grass and soil help us to 
Yläranta, T.: Effect of road traffic on heavy metal concentrations of plants

Table 5. Mean dry matter yield (g/plot or pot) and heavy metal concentrations (mg/kg of dry matter) of spring wheat grain and straw at various distances from the roads at Nurmijärvi and Jokioinen in 1987.

\begin{tabular}{|c|c|c|c|c|c|c|}
\hline & \multicolumn{3}{|c|}{ Nurmijärvi } & \multicolumn{3}{|c|}{ Jokioinen } \\
\hline & $22 \mathrm{~m}$ & $58 \mathrm{~m}$ & $200 \mathrm{~m}$ & $22 \mathrm{~m}$ & $58 \mathrm{~m}$ & $200 \mathrm{~m}$ \\
\hline \multicolumn{7}{|l|}{ Grain } \\
\hline \multicolumn{7}{|l|}{ Plots } \\
\hline Yield & 1700 & 1450 & 1670 & 2060 & 1580 & 1860 \\
\hline $\mathrm{Zn}$ & $30^{b}$ & $30^{b}$ & $34^{a}$ & $33^{a}$ & $33^{a}$ & $37^{2}(1$ \\
\hline $\mathrm{Cu}$ & $3.9^{\mathrm{b}}(1$ & $3.9^{\mathrm{b}}(1$ & $4.9^{\mathrm{a}}(1$ & $4.9^{\mathrm{a}}(1$ & $4.6^{a}(1$ & $5.4^{a}(2$ \\
\hline $\mathrm{Pb}$ & $0.030^{a}$ & $0.019^{a}$ & $0.020^{\mathrm{a}}$ & $0.026^{a}$ & $0.029^{a}$ & $0.016^{\mathrm{a}}$ \\
\hline $\mathrm{Cd}$ & $0.009^{a}(2$ & $0.008^{\mathrm{a}}(2$ & $0.007^{a}(2$ & $0.007^{a}(2$ & $0.008^{a}(2$ & $0.010^{\circ}(3$ \\
\hline $\mathrm{Ni}$ & $0.30^{a}(3$ & $0.25^{a}(3$ & $0.27^{a}(3$ & $0.32^{b}(3$ & $0.41^{\mathrm{ab}}(3$ & $0.45^{\circ}(4$ \\
\hline \multicolumn{7}{|l|}{ Pots } \\
\hline Yield & $28.0^{\mathrm{a}}$ & $24.3^{b}$ & $18.5^{b}$ & $34.5^{\mathrm{a}}$ & $34.9^{a}$ & $33.6^{a}$ \\
\hline $\mathrm{Zn}$ & $37^{\mathrm{a}}$ & $34^{a}$ & $39^{a}$ & $33^{a}$ & $34^{a}$ & $32^{\mathrm{a}}(1$ \\
\hline $\mathrm{Cu}$ & $2.8^{\mathrm{a}}(1$ & $2.4^{\mathrm{a}}(1$ & $2.3^{\mathrm{a}}(1$ & $2.9^{a}(1$ & $2.9^{\mathrm{a}}(1$ & $2.5^{\circ}(2$ \\
\hline $\mathrm{Pb}$ & $0.037^{a}$ & $0.019^{\mathrm{a}}$ & $0.019^{\mathrm{a}}$ & $0.023^{a}$ & $0.018^{\mathrm{a}}$ & $0.015^{\mathrm{a}}$ \\
\hline $\mathrm{Cd}$ & $0.018^{a}(2$ & $0.017^{a}(2$ & $0.029^{a}(2$ & $0.021^{\mathrm{a}}(2$ & $0.019^{a}(2$ & $0.019^{\mathrm{a}}(3$ \\
\hline $\mathrm{Ni}$ & $0.070^{\circ}(3$ & $0.060^{a}(3$ & $0.068^{a}(3$ & $0.052^{a}(3$ & $0.064^{a}(3$ & $0.050^{\mathrm{a}}(4$ \\
\hline \multicolumn{7}{|l|}{ Straw } \\
\hline \multicolumn{7}{|l|}{ Plots } \\
\hline Yield & 3830 & 4020 & 4600 & 6630 & 5590 & 6750 \\
\hline $\mathrm{Zn}$ & $9.3^{\mathrm{ab}}$ & $7.6^{\mathrm{b}}$ & $10.6^{\mathrm{a}}$ & $8.5^{\mathrm{a}}$ & $8.7^{\mathrm{a}}$ & $11.6(1$ \\
\hline $\mathrm{Cu}$ & $1.6^{\mathrm{a}}$ & $1.3^{b}$ & $1.5^{\mathrm{ab}}$ & $1.6^{\mathrm{a}}$ & $1.4^{\mathrm{a}}$ & $1.5^{\mathrm{a}}$ \\
\hline $\mathrm{Pb}$ & $0.88^{a}(1$ & $0.34^{b}$ & $0.28^{b}(1$ & $0.51^{\mathrm{a}}$ & $0.33^{\mathrm{a}}$ & $0.14^{b}(2$ \\
\hline $\mathrm{Cd}$ & $0.061^{a}$ & $0.040^{\mathrm{ab}}(1$ & $0.034^{b}(2$ & $0.067^{\mathrm{a}}$ & $0.056^{\mathrm{a}}(1$ & $0.055^{a}$ \\
\hline $\mathrm{Ni}$ & $0.102^{\mathrm{a}}$ & $0.078^{\mathrm{a}}$ & $0.044^{a}$ & $0.080^{\mathrm{a}}$ & $0.072^{a}$ & $0.044^{a}$ \\
\hline \multicolumn{7}{|l|}{ Pots } \\
\hline Yield & $95.8^{\mathrm{a}}$ & $93.2^{\mathrm{a}}$ & $63.3^{b}$ & $100^{\mathrm{a}}$ & $118^{a}$ & $106^{a}$ \\
\hline $\mathrm{Zn}$ & $10.4^{\mathrm{ab}}$ & $8.1^{\mathrm{b}}$ & $11.6^{\mathrm{a}}$ & $8.9^{a}$ & $9.2^{\mathrm{a}}$ & $8.9^{\mathrm{a}}(1$ \\
\hline $\mathrm{Cu}$ & $1.5^{\mathrm{a}}$ & $1.2^{\mathrm{a}}$ & $1.5^{\mathrm{a}}$ & $1.4^{\mathrm{a}}$ & $1.3^{\mathrm{a}}$ & $1.2^{\mathrm{a}}$ \\
\hline $\mathrm{Pb}$ & $1.10^{\circ}(1$ & $0.33^{b}$ & $0.39^{b}(1$ & $0.44^{a}$ & $0.41^{a}$ & $0.21^{b}(2$ \\
\hline $\mathrm{Cd}$ & $0.092^{b}$ & $0.071^{b}(1$ & $0.117^{a}(2$ & $0.093^{\mathrm{a}}$ & $0.091^{2}(1$ & $0.080^{\mathrm{a}}$ \\
\hline $\mathrm{Ni}$ & $0.082^{a}$ & $0.030^{\mathrm{a}}$ & $0.100^{\mathrm{a}}$ & $0.086^{\mathrm{a}}$ & $0.090^{\mathrm{a}}$ & $0.060^{\mathrm{a}}$ \\
\hline
\end{tabular}

Statistical tests as in Table 4. Grain and straw were tested separately.

understand the slight discrepancies in the results of this study.

In 1988 , the heavy metal concentrations in plants were similar to those in the yields in 1987 (Table 7), which confirmed the results measured on the NU and JO fields in 1987. The lead concentration was often highest at the experimental site nearest the road, although not as clearly as in 1987.

\section{Conclusion}

This study shows that the zinc, copper, lead, cadmium and nickel concentrations along roadsides are low at current traffic densities. The influence of lead emissions extended within $50 \mathrm{~m}$ of the road. The anomalous lead and cadmium concentrations in dry deposition were attributed to wind 
Vol. 4: 35-48.

Table 6. Mean dry matter yield ( $\mathrm{g} / \mathrm{plot}$ or pot) and heavy metal concentrations ( $\mathrm{mg} / \mathrm{kg}$ of dry matter) of rye grass at various distances from the roads at Nurmijärvi and Jokioinen in 1987.

\begin{tabular}{|c|c|c|c|c|c|c|}
\hline & \multicolumn{3}{|c|}{ Nurmijärvi } & \multicolumn{3}{|c|}{ Jokioinen } \\
\hline & $22 \mathrm{~m}$ & $58 \mathrm{~m}$ & $200 \mathrm{~m}$ & $22 \mathrm{~m}$ & $58 \mathrm{~m}$ & $200 \mathrm{~m}$ \\
\hline \multicolumn{7}{|l|}{ I cut } \\
\hline \multicolumn{7}{|l|}{ Plots } \\
\hline Yield & 2120 & 2410 & 1790 & 2270 & 2170 & 2420 \\
\hline $\mathrm{Zn}$ & $22^{a}$ & $18^{b}$ & $19^{a b}(1$ & $20^{a}$ & $21^{a}$ & $22^{a}$ \\
\hline $\mathrm{Cu}$ & $5.8^{\mathrm{a}}$ & $5.2^{\mathrm{a}}$ & $5.5^{\mathrm{a}}$ & $6.5^{\mathrm{a}}(1$ & $6.3^{a}(1$ & $6.4^{a}(1$ \\
\hline $\mathrm{Pb}$ & $0.55^{\mathrm{a}}$ & $0.27^{\circ}(1$ & $0.17^{\mathrm{c}}$ & $0.63^{a}$ & $0.35^{\mathrm{b}}$ & $0.24^{b}$ \\
\hline $\mathrm{Cd}$ & $0.038^{a}(1$ & $0.039^{a}(2$ & $0.023^{a}(2$ & $0.019^{b}(2$ & $0.059^{a}$ & $0.039^{\mathrm{ab}}$ \\
\hline $\mathrm{Ni}$ & $1.19^{\mathrm{a}}(2$ & $0.97^{b}(3$ & $0.98^{b}(3$ & $1.27^{\mathrm{b}}(3$ & $1.57^{a}(2$ & $1.41^{\mathrm{ab}}(2$ \\
\hline \multicolumn{7}{|l|}{ Pots } \\
\hline Yield & $77.0^{a}$ & $74.7^{\mathrm{a}}$ & $68.7^{\mathrm{a}}$ & $91.8^{\mathrm{a}}$ & $87.9^{a}$ & $88.2^{\mathrm{a}}$ \\
\hline $\mathrm{Zn}$ & $22^{a}$ & $22^{a}$ & $25^{\mathrm{a}}(1$ & $22^{a}$ & $22^{a}$ & $20^{a}$ \\
\hline $\mathrm{Cu}$ & $5.5^{\mathrm{a}}$ & $5.1^{\circ}$ & $5.5^{\mathrm{a}}$ & $5.7^{a}(1$ & $5.4^{a}(1$ & $5.0^{2}(1$ \\
\hline $\mathrm{Pb}$ & $0.49^{a}$ & $0.24^{\mathrm{b}}(1$ & $0.18^{b}$ & $0.65^{a}$ & $0.45^{\mathrm{a}}$ & $0.24^{a}$ \\
\hline $\mathrm{Cd}$ & $0.070^{b}(1$ & $0.068^{b}(2$ & $0.117^{a}(2$ & $0.036^{\mathrm{b}}(2$ & $0.064^{a}$ & $0.057^{\mathrm{ab}}$ \\
\hline $\mathrm{Ni}$ & $0.23^{a}(2$ & $0.17^{a}(3$ & $0.20^{\circ}(3$ & $0.25^{a}(3$ & $0.30^{\mathrm{s}}(2$ & $0.25^{a}(2$ \\
\hline \multicolumn{7}{|l|}{ II Cut } \\
\hline \multicolumn{7}{|l|}{ Plots } \\
\hline Yield & 3620 & 3840 & 3900 & 3130 & 3550 & 3360 \\
\hline $\mathrm{Zn}$ & $18^{a}$ & $16^{a}$ & $17^{a}$ & $15^{\mathrm{a}}$ & $14^{a}(1$ & $16^{a}$ \\
\hline $\mathrm{Cu}$ & $6.5^{a}(1$ & $6.0^{\mathrm{a}}(1$ & $6.6^{a}(1$ & $6.1^{\mathrm{a}}(1$ & $5.6^{\mathrm{a}}(2$ & $5.8^{a}(1$ \\
\hline $\mathrm{Pb}$ & $1.25^{\mathrm{a}}$ & $0.86^{\mathrm{b}}$ & $0.56^{c}$ & $0.92^{\mathrm{a}}$ & $0.54^{b}$ & $0.50^{b}$ \\
\hline $\mathrm{Cd}$ & $0.034^{\mathrm{a}}$ & $0.041^{\mathrm{a}}$ & $0.026^{a}(2$ & $0.032^{\mathrm{a}}$ & $0.015^{\mathrm{a}}$ & $0.029^{a}$ \\
\hline $\mathrm{Ni}$ & $1.27^{a}(2$ & $1.16^{\mathrm{a}}(2$ & $1.11^{\mathrm{a}}(3$ & $0.97^{b}(2$ & $1.30^{\circ}(3$ & $1.18^{\mathrm{a}}(2$ \\
\hline \multicolumn{7}{|l|}{ Pots } \\
\hline Yield & $71.8^{\mathrm{a}}$ & $70.0^{\mathrm{a}}$ & $65.8^{\mathrm{a}}$ & $67.0^{\mathrm{a}}$ & $78.2^{\mathrm{a}}$ & $73.2^{\mathrm{a}}$ \\
\hline $\mathrm{Zn}$ & $17^{a}$ & $17^{\mathrm{a}}$ & $16^{a}$ & $16^{a}$ & $16^{a}(1$ & $15^{\mathrm{a}}$ \\
\hline $\mathrm{Cu}$ & $4.7^{a}(1$ & $4.4^{a}(1$ & $4.1^{2}(1$ & $4.7^{a}(1$ & $4.0^{a}(2$ & $3.9^{\mathrm{a}}(1$ \\
\hline $\mathrm{Pb}$ & $1.17^{\mathrm{a}}$ & $0.78^{b}$ & $0.54^{c}$ & $0.84^{a}$ & $0.54^{b}$ & $0.44^{c}$ \\
\hline $\mathrm{Cd}$ & $0.033^{\mathrm{a}}$ & $0.038^{\mathrm{a}}$ & $0.044^{a}(2$ & $0.027^{\mathrm{a}}$ & $0.023^{\mathrm{a}}$ & $0.026^{a}$ \\
\hline $\mathrm{Ni}$ & $0.32^{a}(2$ & $0.26^{a}(2$ & $0.27^{a}(3$ & $0.21^{a}(2$ & $0.25^{\mathrm{a}}(3$ & $0.22^{a}(2$ \\
\hline
\end{tabular}

Statistical tests as in Table 4. The cuts were tested separately.

direction. The heavy metal concentrations varied between different plant species and also between different plant parts. These results are consistent with those published by Yläranta and Sillanpää (1984), and indicate the complexity and difficulty of interpreting the results of plant analyses when estimating the heavy metal sta- tus of respective soils and vice versa. The results obtained in the study of Sillanpää et al. (1988), in which the lead concentrations of different plant species grown side by side at nine locations in Finland, support the contention that most of the lead in crops is airborne. This finding is confirmed here. 
Yläranta, T.: Effect of road traffic on heavy metal concentrations of plants

Table 7. Mean dry matter yield ( $\mathrm{g} /$ plot or pot) and lead concentrations ( $\mathrm{mg} / \mathrm{kg}$ of dry matter) of lettuce, spring wheat grain and straw, and rye grass at various distances from the road at Jokioinen (JO) in 1988. Means not marked with a common letter differ from each other at the 1\% level of significance (Tukey's HSD test). Lead concentrations of different plants grown on the plots and in pots marked with the same number differ from each other at the $1 \%$ level of significance (t-test).

\begin{tabular}{|c|c|c|c|c|c|c|c|c|c|}
\hline & \multicolumn{3}{|c|}{ Jokioinen } & \multirow{2}{*}{$\begin{array}{l}\text { Reference } \\
\text { area }\end{array}$} & & \multicolumn{3}{|c|}{ Jokioinen } & \multirow{2}{*}{$\begin{array}{l}\text { Reference } \\
\text { area }\end{array}$} \\
\hline & $22 \mathrm{~m}$ & $58 \mathrm{~m}$ & $200 \mathrm{~m}$ & & & $22 \mathrm{~m}$ & $58 \mathrm{~m}$ & $200 \mathrm{~m}$ & \\
\hline & & & & & Rye grass & & & & \\
\hline Lettuce & & & & & I cut & & & & \\
\hline Plots & & & & & Plots & & & & \\
\hline Yield & 1280 & 1070 & 1090 & 840 & Yield & 2420 & 2500 & 2130 & 1780 \\
\hline $\mathrm{Pb}$ & $0.58^{\mathrm{a}}$ & $0.54^{\mathrm{a}}$ & $0.53^{\mathrm{a}}$ & $0.67^{a}(1$ & $\mathrm{Pb}$ & $0.55^{\mathrm{a}}(5$ & $0.45^{\mathrm{a}}$ & $0.24^{b}(6$ & $0.22^{\mathrm{b}}$ \\
\hline Pots & & & & & Pots & & & & \\
\hline Yield & $51.1^{\mathrm{a}}$ & $38.3^{\mathrm{ab}}$ & $45.7^{\mathrm{a}}$ & $24.5^{\mathrm{b}}$ & Yield & $74.0^{\mathrm{a}}$ & $79.2^{\mathrm{a}}$ & $66.2^{\mathrm{ab}}$ & $49.3^{b}$ \\
\hline $\mathrm{Pb}$ & $0.66^{a}$ & $0.46^{b}$ & $0.42^{\mathrm{cb}}$ & $0.25^{c}(1$ & $\mathrm{Pb}$ & $0.91^{2}(5$ & $0.54^{b}$ & $0.33^{c}(6$ & $0.29^{c}$ \\
\hline Wheat grain & & & & & II Cut & & & & \\
\hline Plots & & & & & Plots & & & & \\
\hline Yield & 1920 & 2820 & 2760 & 2110 & Yield & 2740 & 2820 & 2760 & 2940 \\
\hline $\mathrm{Pb}$ & $0.033^{\text {ab }}$ & $0.020^{b}$ & $0.047^{a}(2$ & $0.026^{\mathrm{ab}}$ & $\mathrm{Pb}$ & $1.09^{\mathrm{a}}$ & $0.57^{b}$ & $0.38^{\mathrm{bc}}$ & $0.34^{c}$ \\
\hline Pots & & & & & Pots & & & & \\
\hline Yield & $21.0^{b}$ & $32.4^{a}$ & $15.0^{b}$ & $13.4^{b}$ & Yield & $35.9^{\mathrm{ab}}$ & $37.2^{\mathrm{a}}$ & $41.2^{\mathrm{a}}$ & $28.3^{b}$ \\
\hline $\mathrm{Pb}$ & $0.026^{\mathrm{a}}$ & $0.015^{\mathrm{a}}$ & $0.018^{b}(2$ & $0.031^{\mathrm{a}}$ & $\mathrm{Pb}$ & $1.09^{\mathrm{a}}$ & $0.66^{b}$ & $0.44^{b}$ & $0.41^{\mathrm{b}}$ \\
\hline Wheat straw & & & & & III Cut & & & & \\
\hline Plots & & & & & Plots & & & & \\
\hline Yield & 3170 & 2860 & 2580 & 2120 & Yield & 2050 & 1990 & 2370 & 2680 \\
\hline $\mathrm{Pb}$ & $0.67^{\mathrm{a}}$ & $0.49^{\mathrm{ab}}$ & $0.30^{b}(3$ & $0.34^{\mathrm{b}}(4$ & $\mathrm{Pb}$ & $0.66^{\mathrm{a}}$ & $0.56^{\mathrm{a}}$ & $0.26^{\mathrm{b}}$ & $0.30^{b}(7$ \\
\hline Pots & & & & & Pots & & & & \\
\hline Yield & $26.6^{a}$ & $28.1^{\mathrm{a}}$ & $30.0^{\circ}$ & $26.5^{\mathrm{a}}$ & Yield & $20.7^{\mathrm{ab}}$ & $5.6^{c}$ & $25.5^{\mathrm{a}}$ & $19.0^{b}$ \\
\hline $\mathrm{Pb}$ & $0.61^{a}$ & $0.33^{b}$ & $0.15^{b}(3$ & $0.18^{b}(4$ & $\mathrm{Pb}$ & $0.86^{\mathrm{a}}$ & $0.61^{b}$ & $0.29^{\circ}$ & $0.36^{c}(7$ \\
\hline
\end{tabular}

\section{References}

Albasel, N. \& Cottenie, A. 1985. Heavy metal contamination near major highways, industrial and urban areas in Belgian grassland. Water, Air, and Soil Pollution 24: 103-109.

Andersson, A. \& Gustafson, A. 1988. Deposition av spárelement med nederbörden. Swedish University of Agricultural Sciences. Ekohydrologi 26: 5-12.

Anke, M., Groppel, B., Schmidt, A. \& Kronemann, H. 1986. Cadmium deficiency in ruminants. In: 5 . Spurenelement-Symposium, Al, As, Cd, Hg, Ni, Pb, Sn, TI, Si, V. KMU Leipzig, FSU Jena. p. 937-946.

Aunela, L. \& Larjava, K. 1990. Raskasmetallipäästöt Suomessa (Heavy metal emissions in Finland). Technical Research Centre of Finland. Research notes 1181. 64 p. +4 appendixes +2 abstracts.

Collins, J.A. 1984. Roadside lead in New Zealand and its significance for human and animal health. New Zealand Journal of Science 27: 93-97.

Crump, D.R. \& Barlow, P.J. 1982. Factors controlling the lead content of a pasture grass. Environmental Pollution (Series B) 3: 181-192.

Davies, B.E., Conway, D. \& Holt, S. 1979. Lead pollution of London soils: a potential restriction on their use for growing vegetables. Short Note. Journal of Agricultural Science, Cambridge 93: 749-752.

Davis, R.D. \& Carlton-Smith, C. 1980 . Crops as indicators of the significance of contamination of soil by heavy metals. Water Research Centre. Technical Report TR 140. 44 p.

Erviö, R., Mäkelä-Kurtto, R. \& Sippola, J. 1990. Chemical characteristics of Finnish agricultural soils in 1974 and in 1987. In: Kauppi, P. et al. (eds.). Acidification in Finland. Springer-Verlag, Berlin. p. 214-234.

Eskew, D.L., Welch, R. M. \& Norwell, W.A. 1984. Nickel in higher plants. Further evidence for an essential role. Plant Physiology 76: 691-693.

Ho, Y.B. \& Tai, K.M. 1988. Elevated levels of lead and other metals in roadside soil and grass and their use to 


\section{AGRICULTURAL SCIENCE IN FINLAND}

Vol. 4: 35-48.

monitor aerial metal depositions in Hong Kong. Environmental Pollution 49: 37-51.

Hovmand, M.F., Tjell, J.C. \& Mosbaek, H. 1983. Plant uptake of airborne cadmium. Environmental Pollution (Series A) 30: 27-38.

Huang, C.-Y.L. \& Schulte, E.E. 1985. Digestion of plant tissue for analysis by ICP emission spectroscopy. Communication in Soil Science and Plant Analysis 16: 943958.

Jensen, R.A. \& Laxen, D.P.H. 1987. The effect of the phase-down of lead in petrol on levels of lead in air. The Science of the Total Environment 59: 1-8.

Johnston, W.R. \& Harrison, R.M. 1984. Deposition of metallic and organic pollutants alongside the M6 motorway. The Science of the Total Environment 33: 119-127. Kick, H., Burger, H. \& Sommer, K. 1980. Gesamtgehalte an $\mathrm{Pb}, \mathrm{Zn}$, Sn, As, Cd, Hg, Cu, Ni, Cr und Co. Landwirtschaftliche Forschung 33: 12-22.

Lagerwerff, J.V. \& Specht, A.W. 1970. Contamination of roadside soil and vegetation with cadmium, nickel, lead, and zinc. Environmental Science \& Technology 4: 583-586.

Lakanen, E. \& Erviö, R. 1971. A comparison of eight extractants for the determination of plant available micronutrients in soils. Acta Agriculturae Fenniae 123: 223232.

Naturvàrdsverket 1987. Kadmium i miljōn. Bedömningsgrunder. Naturvårdsverket rapport 3317. 76 p.

Paasikallio, A. 1978. The mineral element contents of timothy (Phleum pratense L.). in Finland. II. Aluminium, boron, molybdenum, strontium, lead and nickel. Acta Agriculturae Scandinavica. Supplementum 20: 40-52.

Rodrígues-Flores, M. \& Rodrígues-Castellón, E. 1982. Lead and cadmium levels in soil and plants near highways and their correlation with traffic density. Environmental Pollution (Series B) 4: 281-290.

SFS 3031. Veden typen măăritys. Peroksodisulfaattihapetus. (Finnish standard concerning determination of nitrogen in water. Oxidation with peroxodisulfate). Suomen standardisoimisliitto. Helsinki 1990. 6 p.

SFS 3865. Laskeuman măărittăminen. (Finnish standard concerning measurement of particulate fall out by horizontal deposit gauge). Suomen standardisoimisliitto. Helsinki 1978. 6 p.

Sillanpää, M. \& Jansson, H. 1991. Cadmium and sulphur contents of different plant species grown side by side. Annales Agriculturae Fenniae 30: 407-413.

- \& Jansson, H. 1992. Status of cadmium, lead, cobalt and selenium in soils and plants of thirty countries. FAO Soils Bulletin 65. $183 \mathrm{p}+1$ appendix. Rome.

- , Yläranta, T. \& Jansson, H. 1988. Lead contents of different plant species grown side by side. Annales Agriculturae Fenniae 27: 39-43.

Sippola, J. \& Tares, T. 1978. The soluble content of mineral elements in cultivated Finnish soils. Acta Agriculturae Scandinavica. Supplementum 20: 11-25.

Syvälahti, J. \& Korkman, J. 1978. The effect of applied mineral elements on the mineral content and yield of cereals and potato in Finland. Acta Agriculturae Scandinavica. Supplementum 20: 80-89.

Tjell, J.C., Hovmand, M.F. \& Mosbaek, H. 1979. Atmospheric lead pollution of grass grown in a background area in Denmark. Nature 280: 425-426.

Ward, N.I., Brooks, R.R., Roberts, E. \& Boswell, C.R. 1977. Heavy metal pollution from automotive emissions and its effect on roadside soil and pasture species in New Zealand. Environmental Science and Technology 11: 917-920.

- , Roberts, E. \& Brooks, R.R. 1979. Seasonal variation in the lead content of soils and pasture species adjacent to a New Zealand highway carrying medium density traffic. New Zealand Journal of Experimental Agriculture 7: 347-351.

WHO 1987. Air quality quidelines for Europe. WHO regional publications. European series No. 23. World Health Organization. Regional office for Europe. Copenhagen. $426 \mathrm{p}$.

Wickern, M. \& Breckle, S.-W. 1983. Blei im Eichenholz von Autobahnrand. Ber. Deutsch. Bot. Ges. Bd. 96: 343350.

Yläranta, T. \& Sillanpää, M. 1984. Micronutrient contents of different plant species grown side by side. Annales Agriculturae Fenniae 23: 158-170. 
Yläranta, T.: Effect of road traffic on heavy metal concentrations of plants

\title{
SELOSTUS
}

\section{Maantieliikenteen vaikutus viljelykasvien raskasmetallipitoisuuteen}

\author{
Toivo Yläranta \\ Maatalouden tutkimuskeskus
}

Sinkin, kuparin, lyijyn, kadmiumin ja nikkelin kertymistä lehtisalaattiin, vehnän jyviin ja olkiin sekä italianraiheinään tutkittiin vuonna 1987 Valtatie 3:n varrella Nurmijärvellä ja Valtatie 2:n varrella Jokioisissa 22,58 ja 200 m:n etäisyydellä teiden reunaviivasta. Koe uusittiin Jokioisissa vuonna 1988.

Koepaikoille 1,8 m:n korkeuteen asetetuilla keräimillä kerättiin vuosina 1987 ja 1988 märkälaskeuma ja se osa kuivalaskeumasta, joka vapaasti laskeutuu ilmasta keräimeen. Tämän "kokonaislaskeuman" ohella kerättiin ilman kuivalaskeuma vuonna 1988 pölynkeräimillä suodattimille 22 ja 200 m:n etäisyydellä tiestä. Kuivalaskeumasta mitattiin lyijyja kadmiumpitoisuus. Lyijyn kokonaislaskeuma oli 22 m:n etäisyydellä tiestä $50 \%$ suurempi ja kuivalaskeumakin selvästi suurempi etäisimpään mittauspisteeseen verrattuna. Myös sinkin kokonaislaskeuma pieneni hieman siirryttäessä tietä lähimmästä mittauspaikasta etäisimpään mittauspaikkaan. Kadmiumin kokonais- ja kuivalaskeuma olivat pieniä kaikilla mittauspaikoilla. Lyijyn ja kadmiumin kuivalaskeuma oli suurin silloin, kun tuuli puhalsi tieltä keräimiin päin.

Kasvien raskasmetallipitoisuudet olivat erisuuria eri kasveissa, mutta pitoisuuserot koepaikkojen välillä olivat pieniä. Suurimmat sinkki-, kadmium- ja nikkelipitoisuudet olivat lehtisalaatissa. Myös vehnän jyvien sinkkipitoisuudet ja italianraiheinän nikkelipitoisuudet olivat suuria. Vehnän jyvien ja olkien sekä italianraiheinän kadmiumpitoisuudet olivat pieniä. Vehnän jyvien sinkki- ja kuparipitoisuudet olivat suurempia ja lyijy- ja kadmiumpitoisuudet paljon pienempiä kuin olkien pitoisuudet.

Pääosan sisältämästään lyijystä kasvit ottivat laskeumasta. Tien reunasta $22 \mathrm{~m}: n$ päässä oli kasvien lyijypitoisuus 1,5-3 -kertainen verrattuna $200 \mathrm{~m}: \mathrm{n}$ etäisyydellä tiestä olleeseen kasvupaikkaan. Etäisimmän kasvupaikan kasvien lyijypitoisuus ja lyijylaskeumakin viittasivat tilanteeseen, joka oli "puhtaalla" vertailukoepaikalla Jokioisissa.

Tutkituista raskasmetalleista ainoastaan lyijyllä on ollut merkitystä viljelykasvien "likaajana" maanteiden varsilla. Likaaminen on ulottunut noin $50 \mathrm{~m}: \mathrm{n}$ etäisyydelle tiestä. Pääosa laskeumissa mitatusta lyijystä on ollut peräisin bensiinistä. Koska lyijyä on mitattu myös etäällä maantiestä, on suuri osa liikenteen lyijypäästöistä kulkeutunut todennäköisesti kauas tiestä. 